\title{
An Assessment of Personality-Type of Managers in Nepalese Hotel Industries
}

\author{
Kapil Khanal ${ }^{1}$
}

\begin{abstract}
Hospitality industry is one of the most profitable industries with a high potential for increase, thus being a hospitality manager is one of the most trendy and prestigious jobs of today. It is also a challenging job since, being an effective one is quite complex due to recorded industrial higher heart burn effects, rapid industrial changes in demand, constant trends and severe industrial competition. The purpose of the study is to evaluate the performance variance of the top managers of the five-star hotels of Nepal in respect with their gender. The primary data were received from employees on different level, line-managers of fivestar hotels. Descriptive and explanatory research designs were used. Composite means and correlation coefficients models were used to analyze and interpret the data.

Analysis showed that the female managers generally tend to adopt democratic or participative style while governing people, whereas, male managers induce an autocratic or directive style in their daily performance. Based on the regression analysis, it was determined that the extraversion dimension had a more significant effect than the openness dimension. The extraversion dimension had a negative effect on extrinsic job satisfaction, while the openness dimension had a positive effect. The extraversion and openness dimensions had a weak but statistically significant effect on general job satisfaction. The extraversion dimension had a negative effect on general job satisfaction, while the openness dimension had a positive effect.
\end{abstract}

Keywords: Five-star hotel, Managers' type, Personality-type, Effective hospitability, Job satisfaction.

\section{Introduction}

Personality has been perceived differently by different scholars. The term personality is derived from the Latin word persona meaning a mask. Personality is a patterned body of habits, traits, attitudes and ideas of an individual as these are organized externally into roles and statuses and as they relate internally to motivation, goals and various aspects of selfhood. For example, Robbins and Judge (2005) have stated that personality refers to the sum total of ways in which an individual reacts and interacts with others. Similarly, Luthans (2011) has claimed personality as a means how a person affects others and how he understands and views himself as well as the pattern of inner and outer measurable traits and person-situation

1 Kapil Khanal, PhD is associate professor at Shanker Dev Campus, Kathmandu 
interaction. According to Robert and Burgess, personality is the sum and organization of those traits which determine the role of an individual in group/s.

The present researcher observed from the works of different scholars in this respect so as to confirm the relevance of taking up an idea whether considering varying leadership styles across the different managers working in the field of hospitality in the present Nepalese context. In this discourse, the present researcher could not be confirmed if there was significant difference of the styles opted by the different managers as the past studies provided with mixed findings in this respect. For example, Keer, Bogaert and Trbovic (2009) have concluded that there exists a very narrow difference of the personality traits opted by the male and female executives whereby the female managers were found to be more conscious on people related matters.

In contrary, Kadyrkulova (2008) has identified that the gender of the respective managers was not a strong determinant of their managerial approaches and the male and female leadmanagers were differently superior in different aspects of their leadership traits.

The relationships of the Big Five personality traits to turnover intention are another area of research interest; studies on the topic however have focused on one or two traits, and their results have been incongruous (Timmerman, 2006; Zimmerman, 2008). Whereas positive traits such as extraversion and openness to experience were related to turnover among call center employees (Timmerman, 2006), other positive traits such as emotional stability best predicted negatively employees' intentions to quit, and conscientiousness and agreeableness best predicted negatively actual turnover decisions (Zimmerman, 2008). There seems to be a need for a research to clarify the role of the Big Five personality traits as a set to predict turnover intention.

The above discussions are enough to come to a conclusion that there is still a big room to explore whether the gender of the lead-managers is an instrumental element to determine the personality type indicators of their managerial approaches and also it is equally undecided whether the personality type of these managers is dependent on their gender. In this respect, the present researcher decided to conduct a systematic observation to confirm the role of gender difference in the process of determining leadership styles possessed by the leadmanagers serving in the fore-front of the hospitality institutions in Nepal, specifically in the five-star hotels located in the Kathmandu Valley. As a result, a study entitled " An Assessment of Personality-Type of Managers in Nepalese Hotel Industries" was visualized to address the concern.

\subsection{Statement of the problem}

The preliminary exploration during the stage of problem formulation for this research revealed that most of the five-star hotels in Kathmandu were employing male candidates as mid-level and top-level managers. Similarly, the ongoing practice of equality and unbiased gender culture in the hotel industry was found to be lacking in contrary to evolving global 
practices. Thus, the present researcher was quite concerned to know if the gender of respective manager was really important while raising the professionals in responsible positions in the hospitality industry. As a result, the present researcher devised a single statement of problem that reads as - Can the personality type of the key people leading five-star hotels be measured in respect with their gender?

In other words, the present study was concerned with examining the roles of female managers on the lead as compared to that of male managers. Similarly, this study aimed to assess the gender-wise display of managerial personality traits and compare them with the vested personality type indicators. On the other hand, the study was focused on the trend of placement and status of female managers working in the five-star hotels.

\subsection{Objective of the study}

The main objective of this research was to evaluate the performance variance of the top managers of the five-star hotels of Nepal in respect with their gender. More specifically, this study further aimed-

- To compare the personality traits of top level male and female managers working in the five-star hotels of Nepal,

- To identify the perceived dominant personality traits across the genders of the managers taken into reference of study

- To establish relationship among various personality traits.

\section{Review of Literature}

The main aim of performing review of literature was to get acquainted with the concept of personality and specifically personality traits of the managers serving in the leading 5-star hotels of Nepal. This chapter has been guided by the purpose of getting depth knowledge of personality type indicators in lead-managers of the hotels.

All individuals who have a bachelor degree may guess the first lecture's topic. If the lecture is on philosophy, the first question would be "what is philosophy?" In other words, psychology professors traditionally start their lectures with the following question: What is personality? (Burger, 2006, p.22). Personality may be defined as emotional, interpersonal, experiential and motivational forms that explain behaviors in different situations. It points to psychological traits which are constant in time and which provides reasons for the behaviors of the individual, and these traits constitute a unified combination that shows who the person is while determining his/her emotional, behavioral and cognitive forms (Mount et al., 2005, p. 447).

"Personality" comes from the Latin term "persona." In antique Greece and Rome, actors had masks called "persona" which emphasized the traits they represent on the stage. Later, this term has been used to mean both the person and his/her role in society (Luthans, 1992, p. 85). In many cases, five orthogonal characteristics result from measurement of many people's personality traits and factor analysis as a covariance structure and these are named 
as extroversion, adaptability, self-control, neuroticism and openness towards experience. Based on the studies which support the robustness and versatility of five-factor model, categorization of five-factor model creates a pre organizational structure for important personality traits, if not for all (Cook, 2005, p. 2).

If we are to conclude from these definitions related to personality, it comes out as a unique image of the factors affecting a person's perception, thinking and behaving modes. Being under the constant impact of stimulants coming from inside and outside, personality includes all biological, psychological, hereditary and acquired abilities, motives, feelings, wants, habits and all other behaviors of the individual. In sum, it is possible to see hereditary traits and environmental impacts in the constitution of personality. One may conclude from this that if environment's impact is taken into account, personality reflects to some extent traits common to the community, and to some extent traits common in all humans, and not only traits unique to individual (Yelboga, 2006, p. 198).

As is shown by personality researchers, one of the definitions of personality traits is fivefactor model (McCrae and John, 1990, p. 176). Five-factor model in the explanation of personality was first used in 1960s and gained speed later in 1980s and 1990s. By the late 1980s, personality scientists came to a common agreement on five strong factors of "FiveFactor Model" which provided a meaningful and useful categorization for the organization of complex findings in personality literature (Taggar et al., 1999, p. 901). Due to the frequent emergence of five-factor model of personality in studies conducted according to various methods, these factors are called as "Big Five" in the literature (Burger, 2006, p. 251). In general, "five-factor model" is used as a common term (Carver and Scheier, 2004, p. 66). Many scholars have laid emphasis on numerous components which are considered as the determinant to examine the personality traits. For example, Myers-Briggs (Digman, 1990, as cited in Luthans, 2011) termed four dimensions as the basis of personality traits which include - 1. Social interaction: extrovert or introvert (E or I), 2. Preference for gathering data: sensing or intuitive ( $\mathrm{S}$ or N), 3. Preference for decision making: feeling or thinking (F or T), and 4. Style of making decisions: perceptive or judgmental (P or J).

Again, Costa and McCrae (1992, as cited in Robbins, \& Judge, 2014) have emphasized on five factor model to assess the personality traits of an individual in any setting. These factors include extraversion, neuroticism, agreeableness, conscientiousness and openness to experience.

The concept and definition of any management term is quiet vague. Meaning, an exact and universally accepted definition of discipline like personality is a challenging task. Moreover, different scholars opt it in their own way and perspectives. For example, Mikulincer and Shaver (2015) stated that 'personality refers to individual differences in characteristic patterns of thinking, feeling and behaving.' Similarly, "Personality" derived from the Latin term "Persona" which means (1) a mask worn by theater actors to represent their role and personality in the play; (2) the authentic self, which includes one's intrinsic motivations, emotions, habits, and ideas (Chan, 1996).

Ellis (2008) stated that, personality falls under the heading of things that most people believe 
they understand. In fact, there is probably no domain within any field of knowledge in which more people think they have achieved some expertise. Simply put, most people believe they can know or understand other people. We all try to predict behavior, interpret conversations, and make inferences about others' actions. If someone offends us, acts strangely, or seems excessively kind, we will quickly try to understand their motives. In addition, we often draw inferences about what kind of people they are; that is, what personality traits they may possess. Most of us regard ourselves as competent judges of personality. We make use of our skills in personality assessment on a daily basis; however, most of us would have a difficult time explaining exactly how we draw our conclusions about others.

The Big Five personality traits (Goldberg, 1992; John \& Srivastava, 1999), or the Five-Factor personality traits (McCrae \& Costa, 1987) is a widely researched model of personality that consists of five dimensions: neuroticism (or conversely emotional stability), extraversion, openness to experience, conscientiousness, and agreeableness. Emotional stability refers to the capability of an individual to respond well to stress; extraversion represents outgoingness and sociability; openness to experience is the degree to which one is openminded; consciousness represents the extent to which one performs tasks accurately and thoroughly; and agreeableness refers to one's cooperativeness and consideration (Kyllonen, Walters, \& Kaufman, 2005).

Researchers have attempted to establish the validity of the Big Five personality traits in predicting employee behaviors. Thus, agreeableness predicted hotel employees' job burnout (Kim, Shin, \& Umbreit, 2007), and extroversion was negatively associated, and neuroticism was positively associated with emotional exhaustion among hotel managers (O'Neill \& Xiao, 2010). Studies of the relationships of the Big Five personality traits to employees' turnover intention have produced incongruous results; whereas positive traits such as extraversion and openness to experience were related to turnover intention (Timmerman, 2006), positive traits such as emotional stability, conscientiousness and agreeableness were negatively predictive of turnover intention, and actual turnover (Zimmerman, 2008). We therefore seek to clarify the relationships of the Big Five personality traits as a set to turnover intention.

We believe that studying the Big Five personality traits as a set would enhance its validity in predicting turnover intention. The Big Five personality traits as a set had a multiple correlation of .41 with job satisfaction (Judge, Heller, \& Mount, 2002), and .49 with the motivational criteria (Judge \& Ilies, 2002). The effect sizes of the full set of Big Five personality traits was multiple $\mathrm{R}=.36$ on entrepreneurial intentions, and multiple $\mathrm{R}=.31$ on entrepreneurial performance (H. Zhao, Seibert, \& Lumpkin, 2010). Also, a test among hotel employees would support the utility of the Big Five personality traits as a set in hospitality work and suggest their use in the selection of hotel employees. Results of our study would support the Big Five theory hypothesis of the effects of personality traits on self-concept (hospitality competency) and characteristics adaptations (turnover intention). As the Big Five personality traits are related to positive work behavior, we expect them to negatively relate to negative behavior such as turnover intention, and hypothesized that: 
Hypothesis 1: Thai hotel staff's Big Five personality traits as a set would negatively predict their turnover intention.

Job satisfaction also mediates to reduce negative job behaviors such as counterproductive work behavior and turnover intention. Thus, job satisfaction partially mediated the relationship of agreeableness to organizational and interpersonal counterproductive work behaviors (Mount, Ilies, \& Johnson, 2006). Job satisfaction mediated the relationship of organizational identification to turnover intention (Van Dick et al., 2004), of leader-member exchange to turnover intention (Han \& Jekel, 2011), and of polychronicity to turnover intention (Jang \& George, 2012). There is strong evidence that job satisfaction is dispositionally based (Judge \& Larsen, 2001), and the Big Five personality traits as a set have a multiple correlation of .41 with job satisfaction (Judge et al., 2002). There has yet to be a study on the mediating effect of job satisfaction on the relationship of Big Five personality traits to turnover intention, and support for the role of job satisfaction in this relationship would point to its importance in reducing turnover and organizational costs. We believe that job satisfaction would mediate to reduce turnover intention, and therefore hypothesized that:

Hypothesis 3: Job satisfaction would mediate the relationship of the Big Five personality traits to turnover intention.

Intention to leave an organization is a topic of interest to practitioners and researchers (Babakus, Yavas, \& Karatepe, 2008; Hemdi \& Nasurdin, 2006, 2008; Lv, Xu, \& Ji, 2012). Emotional exhaustion was related to turnover intention among hotel employees in Turkey (Babakus et al., 2008) and China (Lv et al., 2012). Perceptions of distributive justice were significantly related to turnover intention (Hemdi \& Nasurdin, 2008), whereas trust in the organization tended to reduce turnover intention (Hemdi \& Nasurdin, 2006). A metaanalysis involving 155 studies found that turnover intention mediated nearly all relationships of attitudes to turnover (Tett \& Meyer, 1993). As intention to leave an organization is more predictive of employee turnover than overall job satisfaction or organizational commitment (Steel \& Ovalle, 1984), we used turnover intention in our study as a predictor of actual turnover.

Further, this scholar has claimed that, everyday conceptions of personality traits make two key assumptions. First, traits are stable over time. Most people would accept that an individual's behavior naturally varies somewhat from occasion to occasion, but would maintain also that there is a core of consistency which defines the individual's 'true nature': unchangeable spots of the leopard. In other words, there are differences between individuals that are apparent across a variety of situations. We might expect several different contexts such as examinations, social occasions and group discussions. Stability distinguishes traits from more transient properties of the person, such as temporary mood states. Second, it is generally believed that traits directly influence behavior. If a person spontaneously breaks into cheerful song, we might 'explain' the behavior by saying that he or she has a happy disposition. Such lay explanations are, of course, on shaky ground because of the circularity. 
There are amply variables which are used to describe personality. Many of these words have rather similar meanings: precise, careful, meticulous and painstaking would all seem to relate to some common quality of conscientiousness. Such overlapping traits can be grouped together as a broad aspect or dimension of personality. The present research in basic is concerned to a question as: what is the number of such broad dimensions that are needed to describe the main elements of any individual personality. Numerous research efforts have been devoted to drawing up classificatory schemes of fundamental personality dimensions: estimates of the number required range from three to thirty and so on.

\subsection{Conceptual framework}

By pursuing the above theoretical framework, the present researcher has developed an explicit conceptual framework to conduct the study. This conceptual framework is the basis on which the study is constructed:

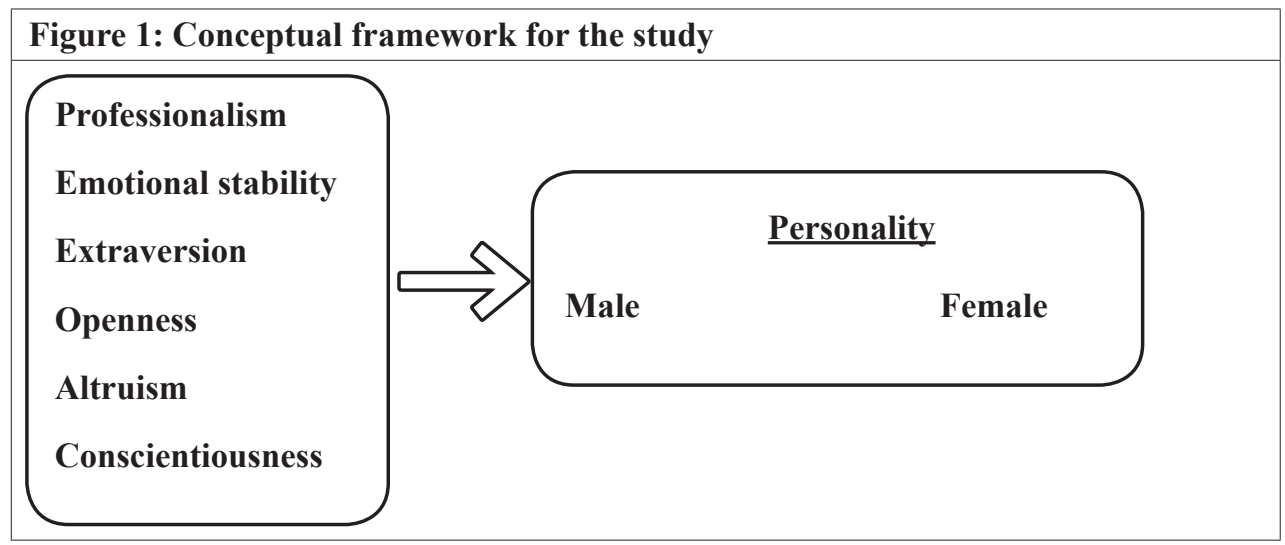

As presented in above figure, the research work holds an assumption that the comparison between the personality traits of male and female managers of 5 star hotels of Nepal is based on independent variables like: Professionalism, Emotional stability, Extraversion, Openness, Altruism, and Conscientiousness. This means, the personality traits of either male or female is differentiated with reference to these mentioned variables. Furthermore, the variation in these variables is the main source to observe and measure the differences in the personality attributes and managerial competencies of genders.

\section{Methodology Used}

\subsection{Research design}

Descriptive and explanatory research designs were applied to meet the objectives of the present research through both quantitative and qualitative methodology as there are limited numbers of 5-star category hotels to be observed and also that simple survey approach will not be sufficient to meet the objective of the study. 


\subsection{Nature and source of data}

In this study primary data were used. The data that were received from employees on different level, line-managers and the information collected from internet, magazines, booklets, journals, newspapers and publications were considered as primary data.

\subsection{Population and sampling technique}

The population of this study comprises the 5-star hotels of Nepal. There are twelve 5-star hotels operating in Nepal at the end of July, 2020. As a sample, 80 of each mid-level staffs (including possible \& equal participation of both the genders) from four 5-star hotels were selected on random sampling technique which will represent all the whole work-force of the 5-star hotels of Nepal. In total, 320 employees from four 5-star hotels were taken to conduct the study.

\subsection{Data collection techniques}

Survey visit was conducted to four 5-star hotels in Kathmandu. A formal interview was conducted with the respondents and information was collected through questionnaires. For the reference different magazines, newspapers and internet sources was considered.

\subsection{Data processing and analysis}

After collecting all level of information they were processed in a systematic manner in accordance with the objective of study. SPSS software is used for the collected data analysis and interpretation.

\subsection{Data presentation and analysis}

\subsubsection{Demographic profiles of respondents}

This section has dealt with the profile of 320 respondents involved in this research study. The study has concentrated on age and work experience as basic profile indicators of the respondents.

Table 1: Demographic profiles of the respondents

\begin{tabular}{|l|c|c|c|}
\hline Age & Male & Female & Total \\
\hline 20 to 30 years & 98 & 102 & 200 \\
\hline Above 30 years & 60 & 60 & 120 \\
\hline Work experience & $60(50.8 \%)$ & $58(48.2 \%)$ & $118(100 \%)$ \\
\hline Up-to 5 years & $98(48.5 \%)$ & $104(51.5 \%)$ & $202(100 \%)$ \\
\hline Above 5 years &
\end{tabular}


The present research comprises of 320 total respondents taken from four 5-star hotels located in the Kathmandu Valley. Among total respondents, 158 are male and 162 are female whereby, in the 20 to 30 year's age group, 98 are male and 102 are female. 60 male and 60 female are interviewed of age group above 30 years. This fact reveals that the female between 20 to 30 years of age are extensively employed in 5-star hotels of Nepal.

Work experience is also examined in course of conducting this research. Among which, 118 respondents had their work experience of up-to 5 years, including 60 i.e. $50.8 \%$ male and 58 i.e. $48.2 \%$ female. Likewise, among 202 respondents having work experience above 5 years, 98 i.e. $48.5 \%$ were male and 104 i.e. $51.5 \%$ were female. Similarly, the above figure concludes that female with work experience above 5 years are dominant in the compared to male employees.

\subsubsection{Perception analysis of respondents}

This section is basically based on the facts and figures computed to analyze the personality traits and its type-indicator. Therefore, responses from the respective respondents are presented in best possible methodology. Each major parameter for the personality type indicators have been descriptively presented in this section.

Table 2: Composite Mean Scores of Personality Variables

\begin{tabular}{|l|c|c|}
\hline Variables & Male & Female \\
\hline Professionalism & 4.31 & 4.24 \\
\hline Emotional stability & 4.18 & 4.13 \\
\hline Extraversion & 4.23 & 4.26 \\
\hline Openness & 4.13 & 4.25 \\
\hline Altruism & 4.16 & 4.15 \\
\hline Conscientiousness & 4.16 & 4.18 \\
\hline
\end{tabular}

Hence, the table 2 draws a conclusion that male managers are professional compared to the female managers. Comparatively, male lead-managers seems to be competent than the female lead-manages in terms of emotional stability. Similarly, female managers are seen more ahead than male when it's a concern of extraversion. In terms of openness also, female seems to be dominant than male lead-mangers. The above total figure reveals that male managers are a little more proficient than female lead- mangers while considering their altruism character. While considering the conscientiousness among the male and female managers, male are seen more conscientious compared to female.

\subsubsection{Measurement of correlation among carious personality traits}

For the purpose of identifying the relationship among various personality traits of the leadmanagers, the present researcher has explored the linkage of those traits. In such, the significant interrelationship among personality traits of the lead-manager is interpreted below: 
Table 3: Measurement of correlation among various personality traits

\begin{tabular}{|c|c|c|c|c|c|c|}
\hline 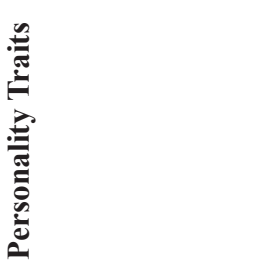 & 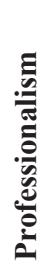 & 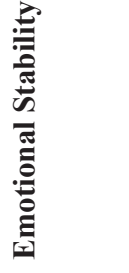 & 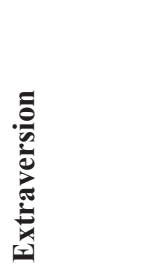 & 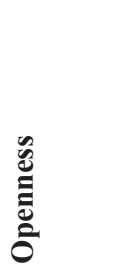 & 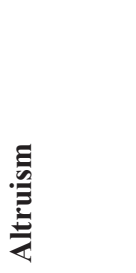 & 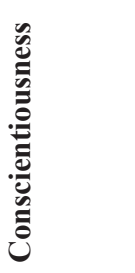 \\
\hline Professionalism & 1 & $0.296 * *$ & $0.197 *$ & $0.385^{* *}$ & $0.290^{* *}$ & 0.140 \\
\hline Emotional Stability & & 1 & $0.297 * *$ & $0.312 * *$ & $0.217 * *$ & $0.186^{*}$ \\
\hline Extraversion & & & 1 & $0.266^{* *}$ & $0.438^{* *}$ & $0.177^{*}$ \\
\hline Openness & & & & 1 & $0.351^{* *}$ & $0.223 * *$ \\
\hline Altruism & & & & & 1 & $0.387 * *$ \\
\hline Conscientiousness & & & & & & 1 \\
\hline
\end{tabular}

**. Correlation is significant at the 0.01 level (2-tailed)

*. Correlation is significant at the 0.05 level (2-tailed)

In table 3, the relationships among the variables are analyzed as: Professionalism is significantly related with emotional stability, openness and altruism under $1 \%$ level of significance. Similarly, the relation between professionalism and extraversion is significant under $5 \%$ level of significance. There is no significant relationship between professionalism and conscientiousness.

Likewise, emotional stability is significantly related with extraversion, openness and altruism under $1 \%$ level of significance, and relation that with conscientiousness is under $5 \%$ level of significance. In such, extraversion is related significantly with openness and altruism under $1 \%$ level of significance whereas; extraversion is significantly related with conscientiousness at 5\% level of significance. Openness has significant relationship with both altruism and conscientiousness under 1\% level of significance. Lastly, altruism and conscientiousness are observed to be significantly related under $1 \%$ level of significance.

\section{Discussion}

The concept of hospitality competency includes skills, abilities, and attitudes that enable hospitality workers to successfully discharge their duties (Tesone \& Ricci, 2005, 2006). We operationally defined hospitality competency to include attitude, communication skills, human relation skills, self-discipline and hospitality technical skills (Zopiatis, 2007), and developed a scale to assess its mediating effect on the Big Five personality traits and turnover intention relationship. Factor analysis of the hospitality competency data revealed a five-factor structure corresponding to the hypothesized dimensions; the scale also exhibited satisfactory reliability. Our results showed that the Big Five personality traits predicted hospitality competency, indicating that hotel employees who scored high in the Big Five 
traits were also competent in their hospitality tasks. The Big Five personality traits and hospitality competency scales we developed may be used in tandem to select hospitality employees.

Although hospitality competency was related to turnover intention it failed to predict turnover intention when age, income, and education were entered as control variables. It seems that turnover intention is also influenced by demographic factors, such that young, highly paid, and well educated hotel employees are likely to have turnover intention. It is also possible that hospitality competency belongs to the domain of job performance and a study on the relationship of hospitality competency to job performance may yield a positive result. More research is needed to establish the relationship of hospitality competency to job performance.

Results of our study add to the literature on the role of job satisfaction as a mediator, and increase our understanding of hotel employees' turnover intention. Job satisfaction mediates the relationship of the Big Five personality traits to turnover intention; the Big Five personality traits as a set seem to increase the level of job satisfaction to negatively predict turnover intention. The relationship of the Big Five personality traits to job satisfaction relationship found in our study seems to support the suggestion that job satisfaction might be dispositionally based (Judge \& Larsen, 2001). The mediation effect of job satisfaction on the relationship of the Big Five personality traits to turnover intention has important implication for hotels; it may be beneficial for hotels to recruit employees who are high in the Big Five personality traits as they tend to be satisfied with their jobs and are unlikely to quit.

\section{Conclusions}

There exists some differences in the personality traits of male and female lead-managers, but they are small. Female employees between age-group 20 to 30 and having work experience above 5 years are extensively employed in 5-star hotels of Nepal. Relation among various personality traits is experienced significant under respective level of significance, except relationship between professionalism and conscientiousness, which is observed to be significantly different. Female generally tend to adopt democratic or participative style while governing people, whereas, male induce an autocratic or directive style in their daily performance. Female managers are more concerned towards people-related issues and quality performance; while male managers seem to attach more importance to an effective performance, control of emotions, concern towards others welfare and specific and careful at works. Female lead-managers basically confront a double bind situation: If they act like a leader, using typically male characteristics, they are perceived as being hard, because they act against the typical female personality profile. If they act like a female, they are perceived as being inefficient, since typically male personality traits are perceived as more effective in terms of performance. Male managers seem to be competent in characteristics like: concerned, careful, helpful, socially confident, organized and meticulous. Contrarily, female are more proficient when it comes to teamwork, communicative and methodological works. 
This research study is based on an exploratory and descriptive research design to meet the objectives of the present research through qualitative and quantitative methodology. This observation based methodology was applied due to less number of 5-star category hotels in Kathmandu Valley, and in Nepal as a whole. Moreover, simply the survey approach would not have been adequate to meet the objectives of the study.

This study concluded that the female managers were reported to confront a double-bind situation in most of the cases where they were blamed to be acting with more harsh attitude towards the people if they acted being practically strict. At the same time, they were again blamed for being inefficient and motherly-loyal towards the employees if they acted with liberal attitude. However the general observation towards the male managers remained more biased in such respects, meaning that the male managers level of strictness, no matter how soft or strict it be, received little concern of the fellow workers. 


\section{References}

Babakus, E., Yavas, U., \& Karatepe, O. M. (2008). The effects of job demands, job resources and intrinsic motivation on emotional exhaustion and turnover intentions: A study in the turkish hotel industry. [Article]. International Journal of Hospitality \& Tourism Administration, 9(4), 384-404.

Burger J. M. (2006). Personality, Istanbul: Kaknus Publications.

Carver C. S. \& Scheier M. F. (2004). Perspectives On Personality, Fifth Edition, Pearson Allyn and Bacon Inc.: New York.

Chan, G. (1996). Images of organizations. Thousand Oaks, CA: Sage Publications. construct of emotional stability in relation to job performance, job satisfaction,

Cook, V. D. (2005). An investigation of the construct validity of the Big Five

Costa, A. H., \& McCrae, B. T. (1992). Gender and leadership style: a meta-analysis. Psychological Bulletin, Sep Vol 108(2), pp. 233 - 256.

Eagly A. H., \& Karau S. J. (2002), "Role congruity theory of prejudice towards female leaders", Psychological Review, 2002, vol. 109, n³, pp. $573-598$.

Ellis, F. M. (2008). The study of personality. Sage Publications.

Goldberg, L. R. (1992). The development of markers for the Big-Five factor structure. Psychological Assessment, 4(1), 26-42. doi: 10.1037/1040-3590.4.1.26

Han, G., \& Jekel, M. (2011). The mediating role of job satisfaction between leader-member exchange and turnover intentions. Journal of Nursing Management, 19(1), 41-49. doi: 10.1111/j.13652834.2010.01184.x

Hemdi, M. A., \& Nasurdin, A. M. (2006). Predicting turnover intentions of hotel employees: The influence of employee eevelopment human resource management practices and trust in organization. [Article]. Gadjah Mada International Journal of Business, 8(1), 21-42.

Hemdi, M. A., \& Nasurdin, A. M. (2008). Investigating the influence of organizational justice on hotel employees' organizational citizenship behavior intentions and turnover intentions. [Article]. Journal of Human Resources in Hospitality \& Tourism, 7(1), 1-23. Homewood, IL: Richard D. Irwin. Retrived on -26th July 2015 Incelenmesi. Is, Guc Endustri Iliskileri ve Insan Kaynaklari Dergisi, 8(2),

Jang, J., \& George, R. T. (2012). Understanding the influence of polychronicity on job satisfaction and turnover intention: A study of non-supervisory hotel employees. International Journal of Hospitality Management, 31(2), 588-595. doi: 10.1016/j.jhm.2011.08.004

Judge, T. A., \& Ilies, R. (2002). Relationship of personality to performance motivation: A meta-analytic review. Journal of Applied Psychology, 87(4), 797-807. doi: 10.1037/0021-9010.87.4.797

Judge, T. A., \& Larsen, R. J. (2001). Dispositional affect and job satisfaction: A review and theoretical extension. Organizational Behavior and Human Decision Processes, 86(1), 67-98. doi: 10.1006/ obhd.2001.2973

Judge, T. A., Heller, D., \& Mount, M. K. (2002). Five-factor model of personality and job satisfaction: A meta-analysis. [Article]. Journal of Applied Psychology, 87(3), 530-541. doi: 10.1037//00219010.873.3.530

Judge, T. A., Heller, D., \& Mount, M. K. (2002). Five-factor model of personality and job satisfaction: 
A meta-analysis. [Article]. Journal of Applied Psychology, 87(3), 530-541. doi: 10.1037//00219010.873.3.530

Kadyrkulova, A. (2008). Female and gender leadership. An unpublished masters thesis. Baltic Business School, University of Kalmar. Available at: http://www.diva-portal.org/smash/get/diva2:238/ fulltext02. Retrieved on: October 21, 2015.

Keer, E. V., Bogaert, J., \& Trbovic, N. (2009). Could the right man for the job be a woman? How women differ from men as leaders. Hudson. Available at: http://nl.hudson.com/Portals/NL/ documents/Could-the-right-man-for-the-job-be-a-woman.pdf. Retrieved on: November 17, 2015.

Kim, H. J., Shin, K. H., \& Umbreit, W. T. (2007). Hotel job burnout: The role of personality characteristics. International Journal of Hopsitality Management, 26(2), 421-434. doi: 10.1016/j. ijhm.2006.03.006

Kyllonen, P. C., Walters, A. M., \& Kaufman, J. C. (2005). Noncognitive constructs and their assessment in graduate education: A review. Educational Assessment, 10(3), 153-184. doi: 10.1207/ s15326977ea1003_2

Luthans, F. (1992). Organizational Behavior, 6.Ed., Mc Graw Hill Company: New York.

Luthans, F. (2011). Organizational behavior: an evidence-based approach. (12th ed.). New Delhi: McGraw-Hill Education (India) Private Limited.

Lv, Q., Xu, S., \& Ji, H. (2012). Emotional labor strategies, emotional exhaustion, and turnover intention: An empirical study of Chinese hotel employees. [Article]. Journal of Human Resources in Hospitality \& Tourism, 11(2), 87-105. doi: 10.1080/15332845.2012.648837

Matsa, D. A., \& Miller, A. R. (2012). Is There a Female Leadership Style? KelloggInsight, 4, September, 2014

McCrae, R. R., \& Costa, P. T. (1987). Validation of the five factor model of personality across instruments and observers. Journal of Personality and Social Psychology, 52(1), 81-90. doi: 10.1037/0022-3514.52.1.81

McCrae, R. R., \& John, O. P. (1992). An introduction to the five factor model and its applications. Journal of personality, 60(2), 175-215.

Mikulincer, M., \& Shaver P. R. (2015). Personality and Social Psychology. APA Handbooks in Psychology.

Mooney, L. (n.d.) Factors affecting leadership styles. Demand media. Available at: http://yourbusiness. azcentral.com/factors-influencing-leadership-styles- $263 . \mathrm{html}$

Mount, M. K., Barrick, M. R., Scullen, S. M., \& Rounds, J. (2005). Higher order

Mount, M., Ilies, R., \& Johnson, E. (2006). Relationship of personality traits and counterproductive work behaviors: The mediating effects of job satisfaction. [Article]. Personnel Psychology, 59(3), 591-622. doi: 10.1111/j.1744-6570.2006.00048.x

O'Neill, J. W., \& Xiao, Q. (2010). Effects of organizational/occupational characteristics and personality traits on hotel manager emotional exhaustion. International Journal of Hopsitality Management, 29, 652-658. doi: 10.1016/j/ijhm.2009.12.004

Robbins. S. P., \& Judge. T. A. (2014). Organizational behavior. (16th ed.). Prentice Hall: Pearson Education Inc. 
Steel, R. P., \& Ovalle, N. K. (1984). A review and meta-analysis of research on the relationship between behavioral intentions and employee turnover. Journal of Applied Psychology, 69(4), 673-686. doi: 10.1037/0021-9010.69.4.673

Taggar, S., Hackew, R., \& Saha, S. (1999). Leadership emergence in autonomous

Tesone, D. V., \& Ricci, P. (2005). Job competency expectations for hospitality and tourism employees: Perceptions of educational preparation. Journal of Human Resources in Hospitality \& Tourism, 4(2), 53-64. doi: 10.1300/J171v04n02_03

Tesone, D. V., \& Ricci, P. (2006). Toward a definition of entry-level job competencies: Hospitality manager perspectives. International Journal of Hospitality \& Tourism Administration, 7(4), 65 80. doi: 10.1300/J149v07n04_04

Tett, R. P., \& Meyer, J. P. (1993). Job satisfaction, organizational commitment, turnover intention, and turnover: Path analyses based on meta-analytic findings. Personnel Psychology, 46(2), 259-293.

Timmerman, T. A. (2006). Predicting turnover with broad and narrow personality traits. International Journal of Selection and Assessment, 14(4), 392-399. types. Personnel Psychology, 58(2), 447478.

Van Dick, R., Christ, O., Stellmacher, J., Wagner, U., Ahlswede, O., Grubba, C., . . Tissington, P. A. (2004). Should I stay or should I go? Explaining turnover intentions with organizational identification and job satisfaction. British Journal of Management, 15(4), 351-360. doi: 10.1111/j.1467-8551.2004.00424.x

Wexley, K., and Yukl, G. (1984). Organizational Behavior and Personnel Psychology.

Wikipedia, the free encyclopedia. (November, 2015).

Yelboga, A. (2006). Kisilik Ozellikleri ve Is Performansi Arasindaki Iliskinin

Zimmerman, R. D. (2008). Understanding the impact of personality traits on individuals' turnover decisions: Ameta-analytic path model. Personnel Psychology, 61(2), 309-348. doi: 10.1111/j.17446570.2008.00115.x

Zopiatis, A. (2007). Hospitality internships in Cyprus: A genuine academic experience or a continuing frustration? International Journal of Contemporary Hospitality Management, 19(1), 65-77. doi: $10.1108 / 09596110710724170$ 